\title{
PERSEPSI MASYARAKAT HUKUM ADAT TERHADAP KEBERADAAN HUTAN DI KASEPUHAN KARANG DAN CISUNGSANG, KABUPATEN LEBAK, BANTEN
}

\author{
(Perception of Customary Law Communities on the Existence of Forest in Kasepuhan \\ Karang and Cisungsang, Lebak Regency, Banten)
}

\author{
Surati, Sylviani, Niken Sakuntaladewi, Dian Charity Hidayat, \& Kuncoro Ariawan \\ Pusat Penelitian dan Pengembangan Sosial Ekonomi Kebijakan dan Perubahan Iklim; Jl. Gunung Batu No. 5, \\ Bogor, Indonesia; email: tatisurati@yahoo.co.id; sylvireg@yahoo.co.id; niken_sakuntaladewi@yahoo.co.uk; \\ dian-charity@gmail.com;kla280572@yahoo.com
}

Diterima 11 September 2020, direvisi 18 Agustus 2021, disetujui 20 Agustus 2021

\begin{abstract}
The existence of customary territories, which are generally located in forest areas, create a separate conflict. One solution is the granting of customary forest management rights to customary law communities (CLC), and there are common understanding and perception between community and forest area managers. The study aims to understand perceptions of CLC about their needs and interests in forests. The research was conducted in Kasepuhan Karang and Cisungsang. Research method is descriptive qualitative. Data processing was done in a tabulated form and analyzed descriptively. The results showed that the perceptions of CLC Kasepuhan Karang and Cisungsang on customary forest management in terms of social, economic, and ecological aspects were generally positive, and that the condition of the Kasepuhan Karang forest is better. It was found that the ranges from social aspects are $45 \%-95 \%$, economic aspects are 39\%-100\%, and ecological aspects are $75 \%-100 \%$. They depend on the forest as a source of life, medicines, and handicraft materials. Forests are also a place for customary rituals, a source of food, a source of water that is preserved and passed down from generation to generation. Customary institutions need to be strengthened with the active participation of traditional elders or the younger generation, so that future generations understand and inherit customary culture values.
\end{abstract}

Keywords: Perception; customary law community; customary forest; Banten.

\begin{abstract}
ABSTRAK
Wilayah adat yang umumnya berada di kawasan hutan, menimbulkan konflik tersendiri. Salah satu penyelesaian konflik kawasan hutan tersebut adalah pemberian hak kelola hutan adat kepada masyarakat hukum adat (MHA) serta adanya pemahaman dan persepsi yang sama antara masyarakat dengan pengelola kawasan hutan. Penelitian bertujuan untuk memahami persepsi MHA mengenai kebutuhan dan kepentingan mereka pada hutan. Penelitian dilakukan di Kasepuhan Karang dan Cisungsang, Banten. Metode penelitian secara kuantitatif dan kualitatif. Pengolahan data dilakukan dalam bentuk tabulasi dan dianalisis secara desikriptif. Hasil penelitian menunjukkan bahwa persepsi MHA Kasepuhan Karang dan Cisungsang terhadap pengelolaan hutan adat ditinjau dari aspek sosial, ekonomi, dan ekologi umumnya positif tetapi kondisi hutan Kasepuhan Karang lebih baik. Dari aspek sosial berkisar antara 45\%-95\%, aspek ekonomi dengan kisaran 39\%-100\%, dan aspek ekologi berkisar 75\%$100 \%$. MHA Kasepuhan Karang dan Cisungsang memiliki hubungan yang jelas antara tanah yang menjadi sumber kehidupan dengan alam sekitarnya. Mereka bergantung pada hutan sebagai sumber kehidupan, obat-obatan, dan bahan kerajinan tangan. Hutan juga menjadi tempat pelaksanaan ritual adat, sumber pangan, sumber mata air yang dipertahankan dan diwariskan dari generasi ke generasi. Kelembagaan adat perlu diperkuat dengan partisipasi aktif dari tetua adat ataupun generasi muda agar generasi penerus memahami dan mewarisi nilai budaya adat.
\end{abstract}

Kata kunci: Persepsi; masyarakat hukum adat; hutan adat; Banten. 


\section{PENDAHULUAN}

Wilayah adat yang umumnya berada di kawasan hutan, menimbulkan konflik tersendiri. Keberlangsungan fungsi sumber daya hutan perlu dikontrol melalui kejelasan hak maupun pengendalian akses yang sangat dipengaruhi oleh tujuan jangka pendek maupun jangka panjang (Kartodiharjo, 2016). Secara teoritis, pemerintah dapat menjaga keberlangsungan fungsi hutan melalui hak-hak yang telah ditetapkan secara hukum tetapi dalam praktiknya terbukti belum mampu menjawab tujuan tersebut (Surati et al., 2018).

Menurut United Nation Declaration on The Rights of Indigenous Peoples (UNRIP) dalam Zakaria (2016), hak-hak masyarakat adat harus diakui dan dihormati, seperti hak atas pemanfaatan tanah, hak turut berpartisipasi dalam sumber daya alam, dan hak menentukan hubungan lembaga pemerintahan hukum adat dengan pemerintah pusat atau negara. Sejak keluarnya Putusan Mahkamah Konstitusi No. 35/PUU-X/2012, kebutuhan akan adanya pengakuan terhadap keberadaan dan hak masyarakat adat dengan wilayah adatnya semakin menguat (Subarudi, 2014; Arizona, Malik, \& Ishimora, 2017; Hidayat et al., 2018). Penguasaan lahan di hutan adat masih sangat tergantung pada penguasaan yang sudah diwariskan secara turun-temurun (Amalia, 2019). Hal ini juga terjadi di beberapa masyarakat hukum adat di sekitar Taman Nasional Gunung Halimun Salak.

Menurut Prabowo, Basuni, \& Suharjito (2010), salah satu penyelesaian konflik kawasan hutan di Taman Nasioal Gunung Haliman Salak (TNGHS) adalah pemberian hak kelola hutan adat kepada masyarakat adat Kasepuhan yang wilayahnya sebagian besar di TNGHS. Termasuk di antaranya adalah Kasepuhan Karang dan Kasepuhan Cisungsang.

Dalam pengelolaan hutan, masyarakat adat kasepuhan mempunyai kearifan lokal tersendiri, dengan membagi hutan ke dalam beberapa fungsi. Di antara fungsi tersebut adalah lahan garapan yang dikelola karena masyarakat adat kasepuhan menggantungkan kehidupannya di sektor pertanian (Surati et al., 2018; Pratiwi, Nitibaskara, \& Salampessy, 2019). Kearifan lokal masyarakat adat kasepuhan tertuang, baik dalam bentuk aturan tertulis maupun aturan tidak tertulis. Pemanfaatan lahan masih didominasi oleh kebun dan sawah. Lahan di hutan adat masih menjadi sumber pendapatan utama masyarakat adat Kasepuhan Karang (Ramdhaiaty, 2018; Amalia, 2019). Berdasarkan latar belakang tersebut, perlu kiranya mengetahui persepsi masyarkat sekitar hutan tentang keberadaan objek dan kondisi potensi sumber daya alam lainnya yang belum dimanfaatkan secara maksimal. Hal ini adalah salah satu cara untuk mencegah terjadinya konflik di kawasan hutan, yaitu dengan adanya pemahaman dan persepsi yang sama antara masyarakat dengan pengelola kawasan hutan.

Hasil penelitian Lestari, Agussabti, \& Alibsyah (2014) di Kabupaten Aceh Besar menyatakan bahwa persepsi masyarakat adat sangat tinggi terhadap hutan, mereka percaya bahwa hutan memberikan manfaat yang besar bagi kehidupan. Namun demikian, partisipasi masyarakat adat tersebut masih sangat kecil terhadap konservasi sumber daya hutan. Oleh karena itu, penting untuk mengetahui persepsi masyarakat hukum adat yang memiliki akses dan melakukan interaksi langsung terhadap kawasan hutan. Persepsi merupakan suatu dasar dari pembentukan sikap atau perilaku (Wahyuni \& Mamonto, 2012; Surati, 2014; Fajrianda, Bakar, \& Syamsidik, 2017).

Penelitian bertujuan untuk memahami persepsi masyarakat hukum adat, khususnya Kasepuhan Karang dan Kasepuhan Cisungsang mengenai kebutuhan dan kepentingan mereka pada hutan. Hasil penelitian diharapkan memberikan 
sumbangan pemikiran kepada pembuat kebijakan dalam memutuskan pengakuan dan penetapan hutan adat, baik pemerintah daerah maupun pemerintah pusat, juga dalam menentukan program-program pemberdayaan masyarakat sekitar hutan. Dengan demikian maka diharapkan akan meningkatkan kesejahteraan masyarakat dan hutan tetap lestari.

\section{METODE PENELITIAN}

\section{A. Lokasi dan Waktu Penelitian}

Penelitian dilakukan pada tahun 2018 di Kasepuhan Karang dan Kasepuhan Cisungsang, Kabupaten Lebak, Provinsi Banten. Pemilihan lokasi penelitian dilakukan dengan mempertimbangkan hutan adat yang telah mendapatkan surat keputusan (SK) penetapan pencantuman oleh Menteri Lingkungan Hidup dan Kehutanan dan yang belum mendapatkan SK penetapan.

Dengan lokasi demikian, diharapkan dapat diketahui apakah ada perbedaan dalam pengelolaan hutan dan persepsi masyarakat sebelum dan sesudah ditetapkan.

\section{B. Pengumpulan Data}

Responden penelitian adalah masyarakat hukum adat di Kasepuhan Karang dan
Kasepuhan Cisungsang, masing-masing berjumlah 30 orang. Responden terdiri dari tokoh adat, tokoh masyarakat, petani penggarap, serta perwakilan dari ibu rumah tangga. Hal ini cukup mewakili antara responden laki-laki dan wanita. Data yang dikumpulkan terdiri dari data primer dan data sekunder. Pengumpulan data menggunakan kuesioner, wawancara mendalam, observasi, dan studi literatur. Kuesioner bersifat terbuka yang memberikan kesempatan pada responden untuk bebas menentukan jawaban yang terkait dengan aspek sosial, ekonomi, dan ekologi. Rincian kuesioner disajikan pada Tabel 1.

\section{Analisis Data}

Pengolahan data dilakukan dalam bentuk tabulasi dan dianalisis secara deskriptif untuk menggambarkan persepsi masyarakat. Batasan persepsi dalam penelitian ini adalah pemahaman responden terkait hutan adat ditinjau dari aspek sosial, ekonomi, dan ekologi.

Menurut Azwar (2010), ada beberapa metode pengungkapan (mengukur) persepsi, di antaranya dengan observasi perilaku, pertanyaan langsung, pengungkapan langsung, skala sikap, dan pengukuran terselubung. Penelitian ini menggunakan

Tabel 1 Daftar kuesioner dari masing-masing aspek

Table 1 List of questionnaires from each aspect

\begin{tabular}{|c|c|c|c|}
\hline No. & $\begin{array}{c}\text { Aspek sosial } \\
(\text { Social aspects) }\end{array}$ & $\begin{array}{c}\text { Aspek ekonomi } \\
\text { (Economic aspects) }\end{array}$ & $\begin{array}{c}\text { Aspek ekologi } \\
\text { (Ecological aspects) }\end{array}$ \\
\hline 1. & $\begin{array}{l}\text { Aturan/hukum dalam pengelolaan } \\
\text { hutan adat }\end{array}$ & $\begin{array}{l}\text { Pentingnya menjaga kawasan } \\
\text { hutan adat }\end{array}$ & $\begin{array}{l}\text { Keberadaan masyarakat hukum } \\
\text { adat di kawasan hutan adat }\end{array}$ \\
\hline 2. & $\begin{array}{l}\text { Sanksi bagi yang melanggar } \\
\text { hukum }\end{array}$ & $\begin{array}{l}\text { Manfaat hutan adat sebagai } \\
\text { sumber mata air }\end{array}$ & $\begin{array}{l}\text { Pengetahuan tentang keberadaan } \\
\text { hutan adat }\end{array}$ \\
\hline 3. & $\begin{array}{l}\text { Adanya norma adat dalam } \\
\text { pengelolaan hutan adat }\end{array}$ & $\begin{array}{l}\text { Manfaat hutan adat sebagai } \\
\text { sumber kayu bakar }\end{array}$ & Kondisi wilayah hutan adat \\
\hline 4. & $\begin{array}{l}\text { Sanksi bagi yang melanggar } \\
\text { norma }\end{array}$ & $\begin{array}{l}\text { Manfaat hutan adat sebagai } \\
\text { sumber lahan garapan }\end{array}$ & $\begin{array}{l}\text { Potensi yang ada di kawasan } \\
\text { hutan adat }\end{array}$ \\
\hline 5. & $\begin{array}{l}\text { Tradisi dalam pengelolaan hutan } \\
\text { adat }\end{array}$ & $\begin{array}{l}\text { Manfaat hutan adat sebagai } \\
\text { sumber pendapatan }\end{array}$ & $\begin{array}{l}\text { Aturan dan syarat dalam } \\
\text { pemanfaatan kawasan hutan adat }\end{array}$ \\
\hline 6. & Keberadaan benda-benda adat & & \\
\hline 7. & Pengetahuan tentang lembaga adat & & \\
\hline 8. & Partisipasi dalam kelembagaan & & \\
\hline
\end{tabular}

Sumber (Source): Data primer (Primary data). 
metode obsrvasi perilaku, pertanyaan langsung, dan pengungkapan langsung.

Persepsi responden dalam penelitian ini terbagi menjadi:

1. Apabila pemahaman responden terhadap hutan dari aspek sosial, ekonomi, dan ekologi tinggi $>50 \%$ maka persepsi masyarakat adalah positif.

2. Apabila pemahaman responden terhadap hutan dari aspek sosial, ekonomi, dan ekologi $<50 \%$ maka persepsi masyarakat adalah negatif.

Robbin (2008) dalam Novayanti, Banuwa, Safe'i, Wulandari, \& Febryano, (2017) menyatakan bahwa persepsi seseorang terhadap suatu objek akan positif apabila sesuai dengan kebutuhannya, sebaliknya akan negatif apabila bertentangan dengan kebutuhannya. Persepsi masyarakat mencerminkan pendapat, keinginan, harapan, dan tanggapan terhadap kegiatan pengembangan suatu wilayah kawasan. Keterlibatan masyarakat lokal perlu dipertimbangkan, mulai dari perencanaan hingga pengelolaan kawasan hutan (Latupapua, 2011; Restiyawan, 2016; Ariawan \& Surati, 2017).

Batasan aspek sosial, ekonomi, dan ekologi dalam penelitian ini adalah:

1. Aspek sosial: keberadaan hukum adat, norma adat, benda-benda adat, kelembagaan, dan pemerintahan adat dalam pengelolaan hutan adat.

2. Aspek ekonomi: pentingnya keamanan hutan, manfaat hutan sebagai sumber kayu, sumber mata air, lahan garapan, dan penghasilan.

3. Aspek ekologi: keberadaan kawasan hutan, pengetahuan tentang hutan, strategi menjaga hutan, kondisi wilayah hutan, potensi kawasan hutan, aturan dan syarat dalam pemanfaatan hutan.

\section{III.HASIL DAN PEMBAHASAN}

\section{A. Gambaran Umum Lokasi Penelitian}

Masyarakat adat di nusantara tidak terpisahkan dari alam, tanah, hutan, dan laut yang mereka warisi dari leluhurnya, dikenal dengan wilayah adat, dan masih memiliki kearifan adat dalam pengelolaan sumber daya alam (Nababan, 2014). Begitu juga masyarakat adat di Kasepuhan Banten Kidul yang merupakan kelompok masyarakat adat sub-etnis Sunda, tinggal di sekitar Gunung Halimun Salak, terutama di wilayah Kabupaten Sukabumi sebelah barat hingga ke Kabupaten Lebak, dan ke utara hingga ke Kabupaten Bogor.

Kasepuhan (sepuh: tua) menunjuk pada adat istiadat lama yang masih dipertahankan dalam kehidupan seharihari. Masyarakat Kasepuhan Banten Kidul melingkupi beberapa desa tradisional dan setengah tradisional yang masih mengakui kepemimpinan adat setempat (Surati et al., 2018).

Berdasarkan Keputusan Bupati Lebak No. 430/Kep.298/Disdikbud/2013 tanggal 22 Agustus 2013 tentang Pengakuan Keberadaan Masyarakat Adat di Wilayah Kesatuan Adat Banten Kidul di Kabupaten Lebak, keberadaan masyarakat adat di wilayah kesatuan adat Banten Kidul meliputi 17 kaolotan (tetua adat), yaitu Kasepuhan Cisungsang, Cisitu, Cicarucub, Ciherang, Citorek, Bayah, Karang, Guradog, Pasireurih, Garung, Karangcombong, Jamrut, Cibedug, Sindangagung, Cikibad, Lebak Larang, dan Babakanrabig. Pemimpin adat di masing-masing kasepuhan digelari Abah, dalam aktivitas pemerintahan adat sehari-hari dibantu oleh para pejabat adat yang disebut baris kolot (kolot: orang tua; kokolot: tetua) (Desmiwati \& Surati, 2018; Surati et al., 2018).

Lokasi penelitian adalah di Kasepuhan Karang dan Kasepuhan Cisungsang, Kabupaten Lebak. Kabupaten Lebak mempunyai luas wilayah 3.305,07 $\mathrm{km}^{2}$. Luas wilayah kawasan hutan di Kabupaten Lebak adalah 109.106,70 ha atau 35\% dari luas wilayah Kabupaten Lebak. 
Karakteristik responden dari Kasepuhan Karang dan Kasepuhan Cisungsang adalah berasal dari penduduk asli yang sejak lahir tinggal dan dibesarkan di desa tersebut. Responden rata-rata tamatan sekolah dasar (SD). Dari Kasepuhan Karang, umur responden berkisar antara 20-75 tahun, sedangkan dari Kasepuhan Cisungsang berumur antara 25-84 tahun. Umur responden cukup mewakili generasi muda hingga generasi tua.

\section{Hutan Adat Kasepuhan Karang}

Kasepuhan Karang terletak di Desa Jagaraksa, Kecamatan Muncang, Kabupaten Lebak, Banten. Desa Jagaraksa terdiri dari delapan kampung yaitu Cibangkala, Kapudang, Cilunglum, Karang, Cikadu, Cimapag, Warungpojok, dan Cibangkala Jalan. Luas Desa Jagaraksa adalah 1.260 ha, terletak 420 mdpl. Jumlah penduduk Desa Jagaraksa adalah 3.070 jiwa (BPS Kabupaten Lebak, 2020b).

Desa Jagaraksa berada di tepi kawasan hutan TNGHS. Hutan adat Kasepuhan Karang ditetapkan KLHK setelah adanya Peraturan Daerah Kabupaten Lebak, Provinsi Banten No. 8 Tahun 2015 tentang Pengakuan, Perlindungan, dan Pemberdayaan Masyarakat Hukum Adat Kasepuhan.

Keputusan Menteri LHK No. 6748/ MenLHK-PSKL/KUM.1/12/2016 tentang Penetapan Hutan Adat Kasepuhan Karang Seluas \pm 462 ha di Desa Jagaraksa Kecamatan Muncang Kabupaten Lebak Provinsi Banten mengeluarkan 462 ha hutan dari kawasan konservasi negara TNGHS dan menetapkannya menjadi hutan adat milik Kasepuhan Karang. Keputusan Menteri LHK No. 6744/MenLHK-PSKL/KUM.1/12/2016 tentang Penetapan Pencantuman Hutan Adat Kasepuhan Karang Seluas \pm 486 ha di Desa Jagaraksa Kecamatan Muncang Kabupaten Lebak Provinsi Banten dalam Peta Kawasan Hutan mencantumkan 24 ha hutan yang tadinya berstatus area penggunaan lain
(APL) dan hutan yang telah dikeluarkan dari status hutan negara tersebut sebagai kawasan hutan.

Dengan demikian, total hutan adat Kasepuhan Karang adalah 486 ha ( $\pm 0,5 \%$ dari luas kawasan hutan di Lebak) dengan fungsi pokok kawasan konservasi yang mengikuti aturan kelola adat Kasepuhan Karang yaitu Tatali Paranti Karuhun. Aturan tersebut berarti mengikuti, menaati, dan mematuhi tuntunan rahasia hidup seperti para karuhun yang memiliki nilai-nilai tidak hanya tataran religious tetapi juga tercermin pada institusi sosial, sistem kepemimpinan, dan cara berinteraksi dengan alam. Luas hutan adat Kasepuhan Karang yang ditetapkan adalah 486 ha, terdiri dari 462 ha hutan konservasi dan 24 ha merupakan APL.

Masyarakat hutan adat(MHA) Kasepuhan Karang berkomitmen menjaga kelestarian hutan dengan kearifan lokal. Kearifan lokal tercermin dari cara pengelolaan hutan yang membgi hutan ke dalam tiga zona yaitu leuweung titipan (kolot), leuweung tutupan, dan leuweung garapan.

\section{Hutan Adat Kasepuhan Cisungsang}

Kasepuhan Cisungsang terletak di tepi kawasan TNGHS, Desa Cisungsang, Kecamatan Cibeber, Kabupaten Lebak, Provinsi Banten. Luas Desa Cisungsang 1.600 ha, terletak 766 mdpl dengan topografi pegunungan. Jumlah penduduk Desa Cisungsang sebanyak 2.549 jiwa (BPS Kabupaten Lebak 2020b).

Kata Cisungsang juga dibentuk dari dua suku kata, 'ci' dan 'sungsang'. Secara harfiah kata 'ci' adalah bentuk singkat dari 'cai' dalam bahasa Sunda yang berarti air. 'Sungsang' dalam bahasa Sunda berarti terbalik atau berlawanan dari keadaan yang sudah lazim. Maka istilah Cisungsang dapat diartikan sebagai air yang mengalir kembali ke hulu (mengalir secara terbalik).

Warga Kampung Cisungsang percaya bahwa kampung mereka merupakan desa pertama yang dibuka oleh Walangsungsang, 
putra dari Prabu Siliwangi. Mereka menyebutnya dengan istilah 'Guru Cucuk' yang dipilih para leluhur untuk dijadikan tempat tinggal. Itulah alasan mengapa Desa Adat Cisungsang disebut Desa Kasepuhan Banten Kidul atau Kesatuan Adat Banten Kidul. Kampung adat lain dalam keluarga Kasepuhan Banten Kidul seperti Ciptagelar, Cicarucub, Citorek, dan lainnya adalah perluasan dari Cisungsang.

Saat ini, Kasepuhan Cisungsang dipimpin oleh Abah Usep Suyatma Sr yang merupakan keturunan ke-4 sejak didirikan sekitar 700 tahun lalu. Selama rentang waktu itu, sudah empat kali kasepuhan ini pindah hingga akhirnya menetap di tempat sekarang. Bertani (bercocok tanam padi) merupakan mata pencaharian pokok masyarakat adat Kasepuhan Cisungsang. Basis pertaniannya adalah berladang tetapi karena pengaruh perkembangan teknologi pertanian, sekarang semakin banyak sawah yang ditanami padi, yang merupakan tanaman pokok istimewa, biasa digunakan untuk ritual adat serentaun, juga merupakan ketahanan pangan masyarakat adat Kasepuhan Cisungsang.

Kasepuhan Cisungsang melaksanakan beberapa ritual, di antaranya adalah ritual malam opatbelas yang dilakukan setiap bulan purnama. Ada juga prah-prahan yaitu cacah jiwa, dilakukan hari Jum'at pertama bulan Muharam. Ritual lainnya yaitu serentaun yang merupakan rasa syukur setelah panen, dilaksanakan satu kali setahun.

Serentaun merupakan akhir dan awal kegiatan sosial masyarakat. Disebut akhir karena pada ritual serentaun seluruh masyarakat adat Kasepuhan Cisungsang memberikan laporan aktivitas setahun ke belakang. Disebut awal karena ketua adat memberikan wejangan-wejangan dan bekal untuk aktivitas setahun ke depan.

Masyarakat adat Kasepuhan Cisungsang juga melaksanakan upacara munar lembur yang dilakukan lima tahun sekali. Menurut Satriadi \& Somantri (2016), upacara tersebut merupakan harapan agar wilayah tempat tinggal mereka diberi kekuatan dalam menghadapi berbagai kejadian yang baik maupun yang buruk, juga sebagai penolak bala.

\section{B. Persepsi MHA terhadap Hutan}

Masyarakat adat kasepuhan menyadari bahwa dalam pengelolaan alam harus menitik-beratkan pada keseimbangan. Apa yang diambil harus berbanding lurus dengan apa yang diberikan terhadap alam (Novianti, 2016; Pratiwi et al., 2019). Masyarakat meyakini bahwa bumi adalah ibu dan langit adalah bapak yang tercermin dalam filosofi "bakti ka indung nu teu ngandung, ka bapa anu teu ngayuga". Konsep tata kelola hutan pada masyarakat adat bersumber dari pengetahuan lokal yang diwariskan secara turun-temurun. Masyarakat adat kasepuhan mengenal tata kelola hutan dengan pengetahuan tentang zonasi dan fungsi kawasan. Masyarakat kasepuhan membagi hutan ke dalam tiga wewengkon/zonasi yaitu leuweung titipan (zona inti), leuweung tutupan (zona rimba), dan leuweung garapan (zona pemanfaatan) (Rahmawati, Darusman, \& Hermawan, 2017).

\section{Leuweung titipan (zona inti)}

Leuweung titipan yaitu hutan yang tidak boleh dimasuki, dikenal juga sebagai hutan larangan. Hutan ini tidak boleh disentuh atau tidak boleh dimasuki oleh masyarakat kasepuhan. Apabila hutan tersebut dimasuki oleh masyarakat maka sesuatu akan terjadi kepada si pelanggar, baik berupa penyak atau yang lainnya (Manuaba, Satya Dewi, \& Kinasih, 2012). Hutan titipan mempunyai fungsi lindung, sebagai sumber air yang mengairi persawahan, juga digunakan untuk kebutuhan sehari-hari masyarakat kasepuhan.

\section{Leuweung tutupan (zona rimba)}

Leuweung tutupan mempunyai fungsi lindung dan produksi. Hutan boleh dimanfaatkan tetapi harus ada izin dari pemangku adat. Leuweung tutupan hanya 
dapat dimanfaatkan untuk keperluan membangun rumah, lokasinya tidak terlalu jauh dari pemukiman (Nuryanto \& Machpudin, 2008; Desmiwati \& Surati, 2018). Leuweung tutupan tidak boleh dibuka apabila di hutan garapan masih tersedia bahan-bahan untuk keperluan membuat rumah.

\section{Leuweung garapan (zona pemanfaatan)}

Leuweung garapan mempunyai fungsi produksi yaitu hutan yang menjadi sumber mata pencaharian masyarakat sehari-hari berupa persawahan, lading, dan kebun, biasa disebut lahan garapan (Desmiwati \& Surati, 2018). Peraturan pada hutan garapan yaitu siapa saja boleh menggarapnya asalkan ada kemauan dan sepersetujuan ketua adat dan kepala desa (jaro) dengan catatan tidak boleh memiliki tanah tersebut secara individu. Untuk lahan persawahan umumnya berupa tanah milik atau surat pemberian hak menggarap.

\section{Persepsi Masyarakat terhadap Hutan Adat dari Aspek Sosial}

\section{Kasepuhan Karang}

Masyarakat adat Kasepuhan Karang umumnya bermata pencaharian sebagai petani dan buruh. Wilayah adat Kasepuhan Karang $80 \%$ berada di kawasan TNGHS dan masyarakat adat tahu bahwa tempat tinggalnya berada di kawasan hutan. Ketergantungan masyarakat terhadap hutan sangat tinggi, rata-rata seminggu sekali masyarakat masuk ke hutan adat. Masyarakat tinggal di desa tersebut umumnya sejak lahir karena turun-temurun berada di wilayah adat Kasepuhan Karang. Jarak tempat tinggal ke hutan adat rata-rata $>1 \mathrm{~km}$.

Dalam pengelolaan hutan adat, ada aturan tertulis dan tidak tertulis yang disepakati masyarakat, berupa perjanjian dengan ketua adat ataupun jaro. Ada sanksi kalau tidak mematuhi aturan, semua patuh karena takut celaka/kualat. Aturan yang tidak tertulis dalam pengelolaan hutan berupa larangan- larangan masuk hutan di hari-hari tertentu, penentuan waktu menanam.

Di Kasepuhan Karang, ada hari yang tidak boleh masuk hutan yaitu hari Rabu, Jum'at, dan Minggu serta tanggal 15 dan 30 setiap bulannya. Tradisi MHA Kasepuhan Karang di antaranya adalah serentaun, ngumbaran pare yaitu membuat obat dari daun yang ditumbuk dan dimasukkan dalam batok kelapa. Setiap kali panen harus ngegembrong yaitu menumbuk lesung, juga melakukan liliuran atau gotong royong. Juga dilakukan tumpengan yang dibawa ke mesjid yakni selamatan ketika padi berbuah, syukuran di lahan garapan pada saat mau potong kayu dan panen padi sawah, serta dilakukan sedekah bumi sebagai ungkapan syukur dan berbagi.

Benda-benda adat biasanya disimpan di imah gede dekat kokolot, saung lesung, dan di leuweung (hutan adat). Kelembagaan di Kasepuhan Karang adalah kokolot yang biasa disebut abah, wakil kokolot, palawari, bengkong, amil, paraji; sedangkan untuk urusan luar ada jaro atau juru basa. Di Kasepuhan Karang, juru basa yang sekaligus menjadi kepala Desa Jagaraksa adalah Jaro Wahid.

Masing-masing kelembagaan sangat bermanfaat karena dapat menyelesaikan masalah, memberi nasihat kepada warga, membantu dalam perayaan dan hajatan warga. Semua lembaga adat berjalan sesuai dengan fungsi dan keahliannya. Lembaga adat tertinggi adalah kokolot/abah, semua warga masyarakat adat Kasepuhan Karang patuh terhadap apa yang disampaikan abah.

\section{Kasepuhan Cisungsang}

Mata pencaharian masyarakat adat Kasepuhan Cisungsang bervariasi tetapi umumnya menjadi petani, penambang, dan buruh. Pamungkas, Thayib, \& Inswiasri (2015) menyatakan bahwa pertambangan emas yang dilakukan merupakan mata pencaharian tambahan masyarakat sekitar, setelah pertanian. 
Wilayah adat Kasepuhan Cisungsang sebagian besar berada di kawasan TNGHS. Masyarakat tahu dan paham bahwa tempat tinggalnya berada di kawasan hutan. Ketergantungan masyarakat terhadap hutan sangat tinggi, rata-rata seminggu sekali masyarakat adat masuk ke hutan adat.

Tansia (2016) menyatakan bahwa dalam tradisi pemanfaatan keanekaragaman hayati, masyarakat adat Cisungsang juga menopang hidupnya dengan mendapatkan sumber makanan dari sekitarnya. Salah satu yang dimanfaatkan dari hasil hutan dan lahan sekitar adalah jamur (Al Ulya, Leksono, \& Khastini, 2017).

Masyarakat tinggal di Kasepuhan Cisungsang umumnya sejak lahir. Jarak antara tempat tinggal dengan kawasan hutan $<1 \mathrm{~km}$ sehingga interaksi antara masyarakat dengan hutan sangat tinggi.

Dalam pengelolaan hutan adat ada aturan tertulis dan tidak tertulis yang disepakati masyarakat adat Kasepuhan Cisungsang. Ada sanksi kalau tidak mematuhi aturan sehingga semua patuh karena takut celaka/ kualat. Aturan yang tidak tertulis dalam pengelolaan hutan berupa larangan-larangan masuk hutan pada waktu tertentu.

Dalam filosofi masyarakat adat Kasepuhan Cisungsang maka hutan harus dijaga untuk kegiatan sehari-hari.
Hutan tidak boleh ditebang, khususnya di ulu cai atau mata air yang merupakan kawasan hutan yang utama dilindungi. Warga akan mendukung apapun program yang dilakukan untuk melestarikan hutan karena dalam kearifan lokal bahwa hutan adat tidak boleh ditebang, harus dipelihara dan dilindungi secara bersama-sama. Ada beberapa larangan di hutan adat, mana areal yang dapat digarap dan mana yang tidak dan hanya dapat digarap kalau diizinkan oleh abah.

Mayarakat memiliki beragam adatistiadat yang masih dipertahankan namun di Kasepuhan Cisungsang sudah tercampur dengan budaya modern. Masyarakat adat tetap mengikuti perkembangan zaman tanpa meninggalkan keragaman adat-istiadatnya.

Persepsi masyarakat terhadap hutan adat dari aspek sosial di kedua kasepuhan disajikan pada Tabel 2 dan Gambar 1.

Berdasarkan Tabel 2 dan Gambar 1 terlihat bahwa masyarakat di kedua kasepuhan menunjukkan persepsi yang positif terhadap aturan-aturan atau hukum adat, baik yang tertulis maupun tidak tertulis dengan persentase masing-masing 95\% dan 77\%. Persepsi terhadap norma adat yang diberlakukan berikut sanksinya juga dipatuhi oleh msyarakat adat, menunjukkan nilai yang positif masing-masing sebanyak

Tabel 2 Aspek sosial MHA Kasepuhan Karang dan Cisungsang

Table 2 Social aspects of ALC Kasepuhan Karang and Cisungsang

\begin{tabular}{|c|c|c|c|c|c|}
\hline \multirow[b]{2}{*}{ No. } & \multirow{2}{*}{$\begin{array}{l}\text { Aspek sosial } \\
\text { (Social aspect) }\end{array}$} & \multicolumn{2}{|c|}{ Kasepuhan Karang } & \multicolumn{2}{|c|}{ Kasepuhan Cisungsang } \\
\hline & & $\begin{array}{c}\text { Uraian } \\
\text { (Description) }\end{array}$ & $\begin{array}{l}\text { Penjelasan } \\
\text { (Remark) }\end{array}$ & $\begin{array}{c}\text { Uraian } \\
\text { (Description) }\end{array}$ & $\begin{array}{l}\text { Penjelasan } \\
\text { (Remark) }\end{array}$ \\
\hline 1. & $\begin{array}{l}\text { Hukum adat } \\
\text { (Customary law) }\end{array}$ & $\begin{array}{l}\text { Hutan titipan } \\
\text { (zona inti) tidak } \\
\text { boleh ditebang }\end{array}$ & $\begin{array}{l}\text { Sumber mata air, } \\
\text { harus dijaga }\end{array}$ & $\begin{array}{l}\text { Hutan titipan tidak } \\
\text { boleh ditebang, harus } \\
\text { dijaga }\end{array}$ & $\begin{array}{l}\text { Sumber mata } \\
\text { air }\end{array}$ \\
\hline 2. & $\begin{array}{l}\text { Norma adat } \\
\text { (Customary } \\
\text { norms) }\end{array}$ & $\begin{array}{l}\text { Tidak menebang } \\
\text { sembarangan, } \\
\text { pohon di sekitar } \\
\text { mata air tidak } \\
\text { boleh ditebang }\end{array}$ & $\begin{array}{l}\text { - Ditanam sebelum } \\
\text { ditebang } \\
\text { - Semua patuh } \\
\text { karena takut } \\
\text { celaka }\end{array}$ & $\begin{array}{l}\text { - Ada hari tertentu } \\
\text { untuk masuk hutan } \\
\text { - Dilarang masuk } \\
\text { hutan larangan dan } \\
\text { menebang di sekitar } \\
\text { sumber air }\end{array}$ & $\begin{array}{l}\text { - Menebang } \\
1 \text { pohon, } \\
\text { menanam } 3 \\
\text { pohon } \\
\text { - Semua } \\
\text { patuh karena } \\
\text { takut kualat }\end{array}$ \\
\hline
\end{tabular}


Tabel 2 Lanjutan

Table 2 Continued

\begin{tabular}{|c|c|c|c|c|c|}
\hline \multirow[b]{2}{*}{ No. } & \multirow[b]{2}{*}{$\begin{array}{l}\text { Aspek sosial } \\
\text { (Social aspect) }\end{array}$} & \multicolumn{2}{|c|}{ Kasepuhan Karang } & \multicolumn{2}{|c|}{ Kasepuhan Cisungsang } \\
\hline & & $\begin{array}{c}\text { Uraian } \\
\text { (Description) }\end{array}$ & $\begin{array}{c}\text { Penjelasan } \\
(\text { Remark })\end{array}$ & $\begin{array}{c}\text { Uraian } \\
\text { (Description) }\end{array}$ & $\begin{array}{c}\text { Penjelasan } \\
\text { (Remark) }\end{array}$ \\
\hline 3. & $\begin{array}{l}\text { Benda/kekayaan } \\
\text { adat } \\
\text { (Customary } \\
\text { objects) }\end{array}$ & $\begin{array}{l}\text { Benda-benda adat } \\
\text { disimpan, dirawat, } \\
\text { dan dijaga }\end{array}$ & $\begin{array}{l}\text { Yang menjaga dan } \\
\text { merawat benda- } \\
\text { benda adat: kokolot, } \\
\text { wakil kokolot, } \\
\text { seluruh masyarakat } \\
\text { adat Kasepuhan } \\
\text { Karang }\end{array}$ & $\begin{array}{l}\text { Benda-benda adat } \\
\text { disimpan, dirawat, } \\
\text { dan dijaga }\end{array}$ & $\begin{array}{l}\text { Yang menjaga } \\
\text { dan merawat } \\
\text { benda-benda } \\
\text { adat: kokolot } \\
\text { (abah), ketua } \\
\text { kampung } \\
\text { (rendangan), } \\
\text { wakil kokolot }\end{array}$ \\
\hline 4. & $\begin{array}{l}\text { Kelembagaan } \\
\text { adat } \\
\text { (Customary } \\
\text { institution) }\end{array}$ & $\begin{array}{l}\text { Kokolot, wakil } \\
\text { kokolot, pangiwa, } \\
\text { palawari, } \\
\text { ronda kokolot, } \\
\text { bengkong, } \\
\text { pande, paraji, } \\
\text { pemerintahan } \\
\text { (jaro) }\end{array}$ & $\begin{array}{l}\text { Lembaga adat dan } \\
\text { lembaga desa terdiri } \\
\text { dari anggota yang } \\
\text { sama sehingga } \\
\text { saling mendukung } \\
\text { dan seiring sejalan }\end{array}$ & $\begin{array}{l}\text { Abah di posisi } \\
\text { tertinggi, di } \\
\text { bawahnya ada } \\
\text { kokolot lembur, } \\
\text { dukun, paraji, amil, } \\
\text { maberang, dan } \\
\text { bengkong }\end{array}$ & $\begin{array}{l}\text { Lembaga adat } \\
\text { dan lembaga } \\
\text { desa terpisah } \\
\text { tetapi saling } \\
\text { koordinasi }\end{array}$ \\
\hline 5. & $\begin{array}{l}\text { Pemerintahan } \\
\text { adat } \\
\text { (Customary } \\
\text { government) }\end{array}$ & $\begin{array}{l}\text { Pemerintahan adat } \\
\text { dipimpin kokolot }\end{array}$ & $\begin{array}{l}\text { Jaro dapat mandat } \\
\text { dari kokolot }\end{array}$ & $\begin{array}{l}\text { Pemerintahan adat } \\
\text { dipimpin oleh } a b a h \text {, } \\
\text { dibantu sesuai dengan } \\
\text { jabatan yang ada pada } \\
\text { lembaga adat }\end{array}$ & $\begin{array}{l}\text { Pemerintahan } \\
\text { adat dan } \\
\text { pemerintahan } \\
\text { desa terpisah }\end{array}$ \\
\hline
\end{tabular}

Sumber (Source): Data primer (Primary data).

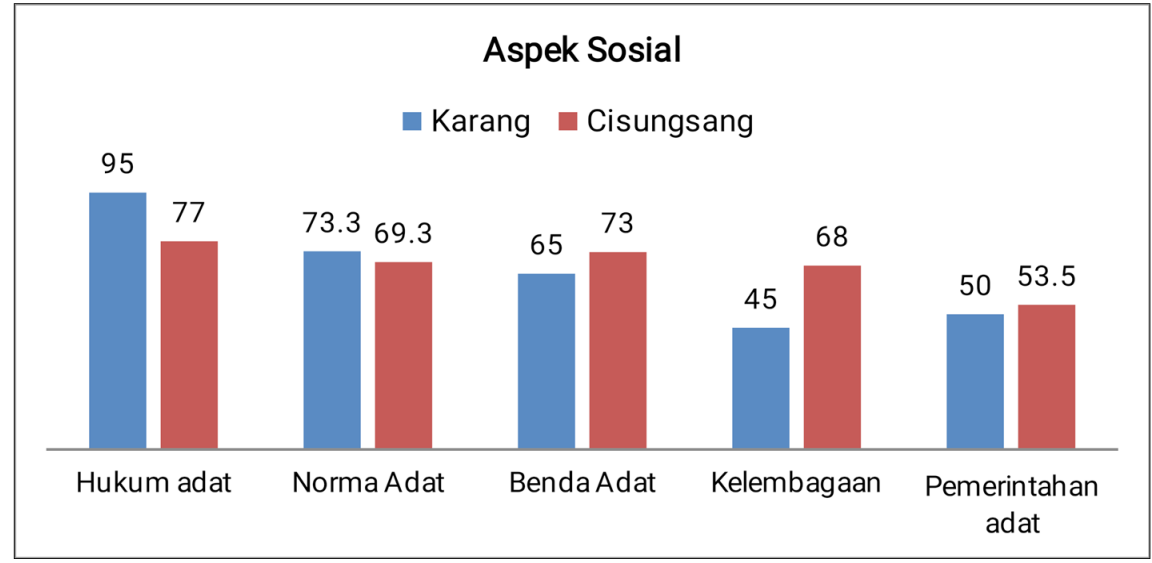

Sumber (Source): Data primer (Primary data).

Gambar 1 Persepsi masyarakat dari aspek ekonomi

Figure 1 Community perceptions from the economi aspects.

$73,3 \%$ dan $69,3 \%$. Hal ini menunjukkan bahwa masyarakat patuh dan mengikuti segala ketentuan yang sudah ditetapkan.
Keberadaan kelembagaan adat di Kasepuhan Karang menunjukkan nilai negatif, hal ini karena sebagian masyarakat 
kurang sepaham dengan ditunjuknya kepala desa dan ditempatkan dalam struktur lembaga adat. Selain itu juga karena banyak dari generasi muda yang belum paham dengan budaya dan kelembagaan yang ada. Perlu transfer pengetahuan dari generasi tua ke generasi muda agar nilai-nilai budaya tidak hilang oleh kemajuan teknologi.

Kelembagaan di Kasepuhan Cisungsang terpisah antara aturan pemerintah desa dan aturan adat. Mayoritas masyarakat lebih patuh kepada perintah adat yang seolaholah menjadi kewajiban padahal kasepuhan tidak pernah memaksa atau memberikan sanksi kepada masyarakat yang melanggar. Menurut mereka, jika ada yang melanggar maka nantinya akan berakibat pada diri masing-masing.

\section{Persepsi Masyarakat terhadap Hutan dari Aspek Ekonomi}

\section{Kasepuhan Karang}

Keberadaan hutan sangat bermanfaat bagi MHA Kasepuhan Karang sebagai sumber penghidupan, baik secara langsung ataupun tidak langsung. Manfaat langsung adalah sebagai penyedia kayu, hasil hutan bukan kayu, lahan tumpangsari, dan sumber air. Manfaat tidak langsung adalah sebagai pengendali banjir dan erosi, kesejukan dan kenyamanan, keindahan alam.

Berdasarkan wawancara mendalam dengan masyarakat adat Kasepuhan Karang, sebagian besar responden (97\%) menyadari pentingnya menjaga hutan untuk generasi yang akan datang. Semua responden berharap agar mereka diikut-sertakan dalam pengelolaan hutan adat. Saat ini, sebagian besar masyarakat telah menggarap lahan di kawasan hutan pada zona leuweung garapan dan leuweung titipan. Sebagian besar mereka menilai bahwa kondisi tegakan hutan adat saat ini sangat baik dan perlu dimanfaatkan secara berkelanjutan.

Masyarakat adat memanfaatkan sumber mata air untuk memenuhi keperluan seharihari. Kebutuhan air setiap harinya mencapai
20 liter/rumah tangga (Hidayat, Surati, Sakuntaladewi, Sylviani, \& Ariawan, 2020). Menyadari bahwa tingkat ketergantungan terhadap sumber mata air cukup tinggi, masyarakat adat berusaha untuk menjaga mata air tersebut dengan menjaga vegetasi di sekitarnya.

Manfaat lain hutan bagi masyarakat adat adalah sebagai sumber kayu, di antaranya kayu bakar, pertukangan, dan untuk dijual. Ketua adat relatif tidak menerapkan aturan adat dalam pemanfaatan dan jumlah pengambilan kayu dari kawasan hutan sehingga tidak ada batasan khusus seberapa besar kayu yang dapat diambil dan dijual oleh masyarakat. Aturan adat sebatas mengatur waktu-waktu tertentu yang dikeramatkan untuk tidak boleh ke hutan dan mengatur penebangan di zona tutupan (wilayah dekat sumber mata air).

Masyarakat dilarang menebang pohon di leuweung titipan. Apabila dilakukan maka harus mengganti dengan menanam tiga buah pohon di tempat yang sama.

Manfaat utama kayu bagi masyarakat Kasepuhan Karang adalah sebagai kayu bakar. Sebanyak 94\% responden mengambil kayu bakar dari pohon yang sudah tumbang alami dan hanya $6 \%$ responden yang mengambil kayu bakar dengan menebang pohon. Pada proses pengambilan ranting untuk kayu bakar, $57 \%$ responden melakukan seleksi dengan hanya mengambil kayu tertentu, sedangkan $43 \%$ responden mengambil semua ranting yang dapat dijangkau. Kayu bakar digunakan untuk keperluan sehari-hari dan kelebihannya untuk dijual. Satu ikat kayu bakar seharga Rp20.000.

Leuweung garapan merupakan lahan budidaya masyarakat di Kasepuhan Karang. Semua responden menilai bahwa kondisi lahan garapan mereka masih dalam kondisi subur. Luas garapan yang dimiliki oleh masyarakat bervariasi. Sebanyak 50\% masyarakat memiliki luas garapan 0,260,5 ha, $23 \%$ memiliki $\leq 0,25$ ha, $20 \%$ 
memiliki 0,51-1 ha, dan 7\% memiliki $>1$ ha. Pembagian lahan didapatkan dari warisan atau turun-temurun dan pembagian dari kokolot.

Lahan garapan masyarakat ditanami tanaman pertanian, tanaman perkebunan, dan tanaman kehutanan dengan sistem tumpangsari. Guna memenuhi kebutuhan pangan sehari-hari, sebanyak $50 \%$ responden menanam padi (Oryza sativa) dan 30\% menanam tanaman pertanian lainnya seperti singkong, jagung, talas, sereh, lengkuas, kacang panjang, ketimum, labu, cabai, dan sayur mayur untuk kebutuhan sendiri.

Dari hasil wawancara, ditetapkannya hutan adat di Kasepuhan Karang sangat berpengaruh terhadap hasil pertanian. Masyarakat mengelola lahan garapan dengan optimal tanpa harus takut pada aparat yang menjaga keamanan kawasan hutan TNGHS. Saat ini telah terjalin komunikasi yang baik antara masyarakat dengan pengelola kawasan.

Tanaman kehutanan dan perkebunan yang digunakan untuk memenuhi kebutuhan berkala yang hasilnya dijual pada waktu tertentu, antara lain: kayu afrika, jeunjing, kadu atau durian, manggis, petai, jengkol, karet, kopi, duku, meranti, mahoni, sengon, rambutan, dan pisang. Selain itu, sebagian masyarakat melakukan budidaya ikan, antara lain: ikan emas dan mujair untuk pemenuhan kebutuhan keluarga. Apabila kebutuhan keluarga sudah terpenuhi, kelebihan hasil panen tanaman perkebunan dan kehutanan dijual kepada tengkulak yang datang ke desa.

\section{Kasepuhan Cisungsang}

Mayarakat adat Kasepuhan Cisungsang membuka lahan dengan cara ditebang habis dan dibakar. Sebelum melakukannya maka harus mendapatkan izin dari kokolot.

Pada proses penanaman, terdapat beberapa ritual adat yang harus dilakukan. Sebagai contoh, pada penanaman padi maka petani harus melakukan ngumbaran pare yaitu membuat obat padi yang mau berbuah, menggunakan daun-daunan yang ditumbuk dan dimasukkan ke dalam batok kelapa. Dalam proses pengelolaannya, sebagian besar masyarakat mengolah lahan garapannya dengan sistem tumpangsari.

Dalam mengolah lahan, terdapat beberapa kendala yang dihadapi oleh masyarakat, baik dari segi bahan pendukung produksi maupun cuaca. Sebagian besar petani menganggap bahwa ketersediaan pupuk di desa masih minim untuk tanaman padi. Selain itu, petani mengeluhkan hasil panen yang berkurang ketika musim hujan. Terlebih lagi adanya hama babi hutan, hama ulat, dan burung yang menyebabkan tanaman lambat berbuah.

Tabel 3 dan Gambar 2 menunjukkan bahwa persepsi masyarakat kedua kasepuhan terhadap keberadaan hutan adat dari aspek ekonomi, rata-rata positif yakni $>90 \%$. Hal ini menunjukkan bahwa hutan adat sangat

Tabel 3 Aspek ekonomi MHA Kasepuhan Karang dan Cisungsang

Table 3 Economic aspects of ALC Kasepuhan Karang and Cisungsang

\begin{tabular}{|c|c|c|c|c|c|}
\hline \multirow[b]{2}{*}{ No. } & \multirow{2}{*}{$\begin{array}{l}\text { Aspek ekonomi } \\
\text { (Economic } \\
\text { aspect })\end{array}$} & \multicolumn{2}{|c|}{ Kasepuhan Karang } & \multicolumn{2}{|c|}{ Kasepuhan Cisungsang } \\
\hline & & $\begin{array}{c}\text { Uraian } \\
\text { (Description) }\end{array}$ & $\begin{array}{c}\text { Penjelasan } \\
(\text { Remark })\end{array}$ & $\begin{array}{c}\text { Uraian } \\
\text { (Description) }\end{array}$ & $\begin{array}{c}\text { Penjelasan } \\
\text { (Remark) }\end{array}$ \\
\hline 1. & $\begin{array}{l}\text { Penting menjaga } \\
\text { hutan } \\
\text { (It's important to } \\
\text { protect the forest) }\end{array}$ & 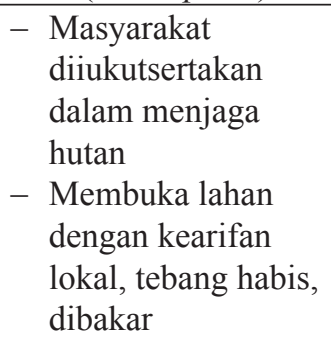 & $\begin{array}{l}\text { - Kalau tidak patuh } \\
\text { takut celaka } \\
\text { - Perlu mendapat } \\
\text { izin dari kokolot }\end{array}$ & $\begin{array}{l}\text { Pembukaan lahan } \\
\text { dengan kearifan } \\
\text { lokal, ditebang } \\
\text { habis, dan dibakar }\end{array}$ & $\begin{array}{l}\text { Perlu } \\
\text { mendapat izin } \\
\text { dari ketua adat }\end{array}$ \\
\hline
\end{tabular}


Tabel 3 Lanjutan

Table 3 Continued

\begin{tabular}{|c|c|c|c|c|c|}
\hline \multirow[b]{2}{*}{ No. } & \multirow{2}{*}{$\begin{array}{c}\text { Aspek ekonomi } \\
\text { (Economic } \\
\text { aspect })\end{array}$} & \multicolumn{2}{|c|}{ Kasepuhan Karang } & \multicolumn{2}{|c|}{ Kasepuhan Cisungsang } \\
\hline & & $\begin{array}{c}\text { Uraian } \\
\text { (Description) }\end{array}$ & $\begin{array}{c}\text { Penjelasan } \\
(\text { Remark })\end{array}$ & $\begin{array}{c}\text { Uraian } \\
\text { (Description) }\end{array}$ & $\begin{array}{c}\text { Penjelasan } \\
(\text { Remark })\end{array}$ \\
\hline 2. & $\begin{array}{l}\text { Manfaat sumber } \\
\text { mata air } \\
\text { (Benefit of springs } \\
\text { sources) }\end{array}$ & $\begin{array}{l}\text { Kondisi air di kawasan } \\
\text { hutan adat adalah baik, } \\
\text { air mengalir setiap hari }\end{array}$ & $\begin{array}{l}\text { Untuk keperluan } \\
\text { irigasi, mandi dan } \\
\text { cuci }\end{array}$ & $\begin{array}{l}\text { Kondisi air di } \\
\text { kawasan hutan } \\
\text { adat adalah baik, } \\
\text { air mengalir setiap } \\
\text { hari }\end{array}$ & $\begin{array}{l}\text { Untuk sumber } \\
\text { air minum, } \\
\text { mandi dan } \\
\text { cuci, irigasi }\end{array}$ \\
\hline 3. & $\begin{array}{l}\text { Manfaat sumber } \\
\text { kayu bakar } \\
\text { (Benefits of } \\
\text { fireswood souces) }\end{array}$ & $\begin{array}{l}\text { Untuk kayu bakar dan } \\
\text { pertukangan }\end{array}$ & $\begin{array}{l}\text { Dari pohon yang } \\
\text { tumbang dan } \\
\text { ranting pohon } \\
(94 \%)\end{array}$ & $\begin{array}{l}\text { Untuk kayu bakar } \\
\text { dan pertukangan }\end{array}$ & $\begin{array}{l}\text { Dari pohon } \\
\text { yang tumbang } \\
\text { dan ranting } \\
\text { pohon } \\
(74 \%) \text { dan } \\
\text { lainnya tidak } \\
\text { memanfaatkan } \\
\text { kayu bakar }\end{array}$ \\
\hline 4. & $\begin{array}{l}\text { Manfaat sumber } \\
\text { lahan garapan } \\
\text { (Benefits of arable } \\
\text { land sources) }\end{array}$ & $\begin{array}{l}\text { Sebanyak } 94 \% \\
\text { menggarap lahan pada } \\
\text { leuweung garapan }\end{array}$ & $\begin{array}{l}\text { Kondisi lahan } \\
\text { garapan yang subur } \\
(100 \%) \text {, ditanami } \\
\text { tanaman pertanian } \\
\text { dan kehutanan }\end{array}$ & $\begin{array}{l}\text { Sebanyak } 39 \% \\
\text { menggarap lahan } \\
\text { pada leuweung } \\
\text { garapan }\end{array}$ & $\begin{array}{l}\text { Kondisi lahan } \\
\text { garapan yang } \\
\text { subur }(75 \%) \text {, } \\
\text { ditanami } \\
\text { tanaman } \\
\text { pertanian dan } \\
\text { kehutanan }\end{array}$ \\
\hline 5. & $\begin{array}{l}\text { Manfaat sumber } \\
\text { penghasilan } \\
\text { (Benefits of } \\
\text { income sources) }\end{array}$ & $\begin{array}{l}\text { Hasil dari lahan } \\
\text { garapan untuk } \\
\text { kebutuhan sendiri dan } \\
\text { dijual }(90 \%)\end{array}$ & $\begin{array}{l}\text { Lahan } \\
\text { dimanfaatkan juga } \\
\text { untuk kolam ikan }\end{array}$ & $\begin{array}{l}\text { Hasil dari lahan } \\
\text { garapan untuk } \\
\text { kebutuhan sendiri } \\
\text { dan dijual }(70 \%)\end{array}$ & $\begin{array}{l}\text { Lahan } \\
\text { dimanfaatkan } \\
\text { juga untuk } \\
\text { kolam ikan dan } \\
\text { ternak }\end{array}$ \\
\hline
\end{tabular}

Sumber (Source): Data primer (Primary data).

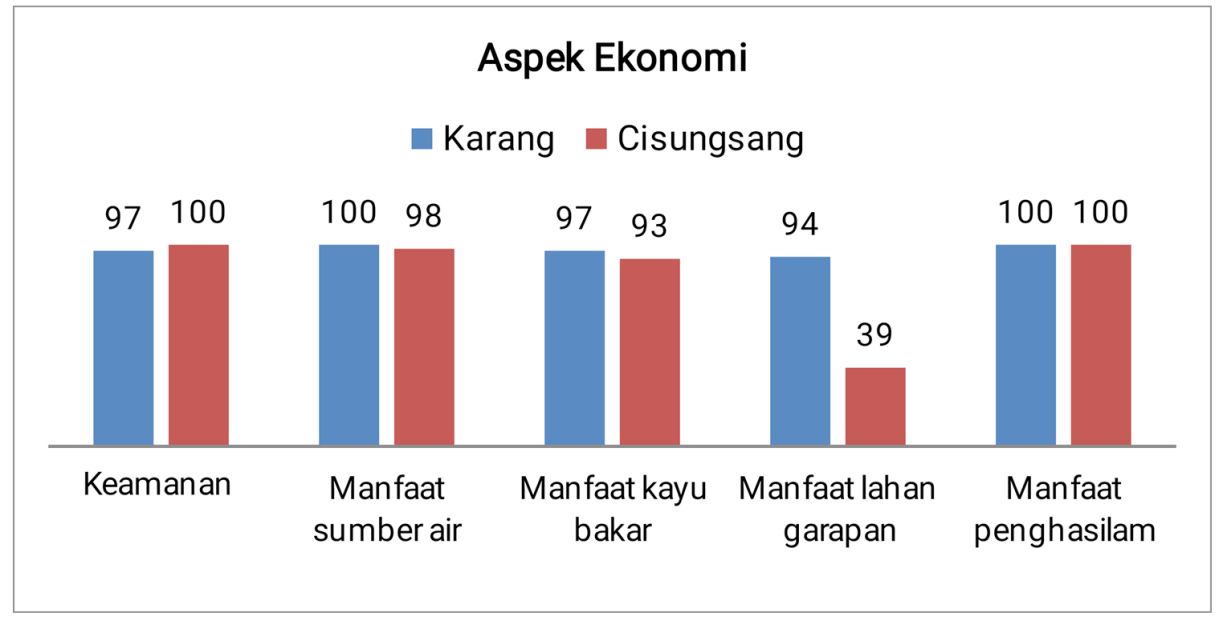

Sumber (Source): Data primer (Primary data)

Gambar 2 Persepsi masyarakat dari aspek ekonomi

Figure 2 Community perceptions from the economi aspects. 
bermanfaat bagi perekonomian masyarakat. Pemanfaatan lahan garapan di Kasepuhan Cisungsang menunjukkan persepsi negatif yakni $<50 \%$. Hal ini disebabkan keterbatasan sarana produksi dan banyak hama yang menyebabkan produksi menurun.

Dari hasil wawancara mendalam dengan perangkat adat dan masyarakat, penetapan hutan adat juga sangat berpengaruh. Masyarakat berharap agar segera ditetapkan oleh Kementerian Lingkungan Hidup dan Kehutanan sebagai hutan adat. Dengan penetapan hutan adat maka masyarakat akan mengelola lahan garapan secara maksimal tanpa takut dikejar-kejar pengelola kawasan.

\section{E. Persepsi Masyarakat terhadap Hutan dari Aspek Ekologi}

Faktor ekologi di antaranya terkait dengan iklim atau cuaca dan vegetasi. Musim kemarau yang berkepanjangan mengakibatkan rusaknya sawah dan ladang sehingga masyarakat sebagai petani tidak bisa lagi bercocok tanam (Fajrianda et al., 2017; Ariawan \& Surati, 2017; Sylviani, Surati, Sakuntaladewi, \& Sumirat, 2020).

Secara keseluruhan, persepsi masyarakat hukum adat Kasepuhan Karang dan Kasepuhan Cisungsang terhadap hutan untuk aspek ekologi adalah positif, sebagaimana ditunjukkan pada Tabel 4 dan Gambar 3. Sebagian besar responden (96\%) di Kasepuhan Cisungsang sudah sejak lahir tinggal di kawasan hutan, sedangkan di Kasepuhan Karang 100\% sudah sejak lahir tinggal di kawasan hutan. MHA di Kasepuhan Karang dan Cisungsang tahu bahwa hutan harus dijaga dan dilindungi bersama-sama terutama bagian hulu yang merupakan sumber air. Hutan merupakan warisan kasepuhan di mana terdapat banyak tanaman yang perlu dipelihara dan dilestarikan. Lahan yang akan digarap harus izin sesepuh adat (abah). Hutan yang dapat digarap adalah zonasi tertentu dengan fungsi produksi sedangkan zonasi larangan tidak boleh digarap. Kawasan hutan tersebut sudah digarap secara turun-temurun.

Responden umumnya tidak mengetahui secara pasti luas hutan adat tetapi 100\% persepsi masyarakat positif, baik di Kasepuhan Karang maupun Cisungsang. Mereka juga mengetahui bahwa kondisinya dalam keadaan baik. Untuk batas kawasan hutan, hanya sebagian responden yang mengetahui.

Berdasarkan Tabel 4 dan Gambar 3, persepsi masyarakat terhadap potensi hutan

Tabel 4 Aspek ekologi MHA Kasepuhan Karang dan Cisungsang

Table 4 Ecological aspects of ALC Kasepuhan Karang and Cisungsan

\begin{tabular}{|c|c|c|c|c|c|}
\hline \multirow[b]{2}{*}{ No. } & \multirow{2}{*}{$\begin{array}{c}\text { Aspek ekologi } \\
\text { (Ecological } \\
\text { aspect) }\end{array}$} & \multicolumn{2}{|c|}{ Kasepuhan Karang } & \multicolumn{2}{|c|}{ Kasepuhan Cisungsang } \\
\hline & & $\begin{array}{c}\text { Uraian } \\
\text { (Description) }\end{array}$ & $\begin{array}{c}\text { Penjelasan } \\
\text { (Remark) }\end{array}$ & $\begin{array}{c}\text { Uraian } \\
\text { (Description) }\end{array}$ & $\begin{array}{c}\text { Penjelasan } \\
\text { (Remark) }\end{array}$ \\
\hline 1. & $\begin{array}{l}\text { Keberadaan HA } \\
\text { (The existence of } \\
\text { customary forest) }\end{array}$ & $\begin{array}{l}\text { Tahu tentang } \\
\text { keberadaan hutan } \\
\text { adat }(100 \%)\end{array}$ & $\begin{array}{l}\text { Generasi tua } \\
\text { paham tentang } \\
\text { hutan adat, } \\
\text { generais muda } \\
\text { kurang paham }\end{array}$ & $\begin{array}{l}\text { Tahu tentang } \\
\text { keberadaan } \\
\text { hutan adat }(94 \%)\end{array}$ & $\begin{array}{l}\text { Generasi tua } \\
\text { paham tentang } \\
\text { hutan adat, } \\
\text { generais muda } \\
\text { kurang paham }\end{array}$ \\
\hline 2. & $\begin{array}{l}\text { Pengetahuan } \\
\text { tentang fungsi HA } \\
\text { (Knowledge of } \\
\text { customary forest) }\end{array}$ & $\begin{array}{l}\text { Sebagai hutan } \\
\text { konservasi }\end{array}$ & $\begin{array}{l}\text { Hanya sebagian } \\
\text { kecil yang paham } \\
\text { bahwa fungsinya } \\
\text { sebagai hutan } \\
\text { konservasi, } \\
\text { masyarakat } \\
\text { hanya tahu } \\
\text { tidak menebang } \\
\text { sembarangan }\end{array}$ & $\begin{array}{l}\text { Sebagai hutan } \\
\text { konservasi }\end{array}$ & $\begin{array}{l}\text { Sebagian kecil } \\
\text { yang tahu fungsi } \\
\text { hutan, masyarakat } \\
\text { hanya paham } \\
\text { bahwa hutan } \\
\text { harus dijaga, } \\
\text { dilestarikan, dan } \\
\text { dilindungi }\end{array}$ \\
\hline
\end{tabular}


Tabel 4 Lanjutan

Table 4 Continued

\begin{tabular}{|c|c|c|c|c|c|}
\hline \multirow[b]{2}{*}{ No. } & \multirow{2}{*}{$\begin{array}{l}\text { Aspek ekologi } \\
\text { (Ecological } \\
\text { aspect) }\end{array}$} & \multicolumn{2}{|c|}{ Kasepuhan Karang } & \multicolumn{2}{|c|}{ Kasepuhan Cisungsang } \\
\hline & & $\begin{array}{c}\text { Uraian } \\
\text { (Description) }\end{array}$ & $\begin{array}{c}\text { Penjelasan } \\
\text { (Remark) }\end{array}$ & $\begin{array}{c}\text { Uraian } \\
\text { (Description) }\end{array}$ & $\begin{array}{c}\text { Penjelasan } \\
\text { (Remark) }\end{array}$ \\
\hline 3. & $\begin{array}{l}\text { Kondisi wilayah } \\
\text { HA (Condition of } \\
\text { costomary forest } \\
\text { area) }\end{array}$ & $\begin{array}{l}\text { - Kearifan } \\
\text { lokal dalam } \\
\text { mengelola hutan } \\
\text { berdasarkan } \\
\text { kontur dan } \\
\text { kemiringan tanah } \\
\text { - Kondisi hutan } \\
\text { adat saat ini } \\
\text { 100\% baik }\end{array}$ & $\begin{array}{l}\text { - Aib lembur: } \\
\text { sumber mata air } \\
\text { - Gunung kayuan: } \\
\text { hamparan kayu } \\
\text { yang tidak boleh } \\
\text { ditebang } \\
\text { - Lamping awian: } \\
\text { lahan curam } \\
\text { yang ditanam } \\
\text { untuk menahan } \\
\text { longsor } \\
\text { - Lebak sawahan: } \\
\text { sumber pangan } \\
\text { - Legok balogan: } \\
\text { kolam dan } \\
\text { pemukiman }\end{array}$ & $\begin{array}{l}\text { Kondisi hutan } \\
75 \% \text { baik }\end{array}$ & $\begin{array}{l}\text { Pengaruh abah } \\
\text { sangat besar } \\
\text { dalam menjaga } \\
\text { kelestarian hutan } \\
\text { karena masyarakat } \\
\text { tidak akan berani } \\
\text { memanfaatkan } \\
\text { hutan tanpa seizin } \\
\text { abah }\end{array}$ \\
\hline 4. & $\begin{array}{l}\text { Potensi HA } \\
\text { (Customary forest } \\
\text { potential) }\end{array}$ & $\begin{array}{l}\text { Hasil hutan kayu } \\
\text { dan bukan kayu }\end{array}$ & $\begin{array}{l}\text { Tanaman pertanian, } \\
\text { buah-buahan, } \\
\text { kayu-kayuan, air, } \\
\text { dan wisata }\end{array}$ & $\begin{array}{l}\text { Hasil hutan kayu } \\
\text { dan bukan kayu }\end{array}$ & $\begin{array}{l}\text { Tanaman } \\
\text { pertanian, buah- } \\
\text { buahan, kayu, } \\
\text { air, dan potensi } \\
\text { tambang emas }\end{array}$ \\
\hline 5. & $\begin{array}{l}\text { Aturan } \\
\text { pemanfaatan HA } \\
\text { (Rules for the } \\
\text { use of customary } \\
\text { forest) }\end{array}$ & $\begin{array}{l}\text { Pohon tidak boleh } \\
\text { ditebang }\end{array}$ & $\begin{array}{l}\text { Pemanfaatan hutan } \\
\text { adat harus seizin } \\
\text { kokolot }\end{array}$ & $\begin{array}{l}\text { Pohon tidak } \\
\text { boleh ditebang }\end{array}$ & $\begin{array}{l}\text { Pemanfaatan } \\
\text { hutan adat harus } \\
\text { seizin } a b a h\end{array}$ \\
\hline
\end{tabular}

Sumber (Source): Data primer (Primary data).

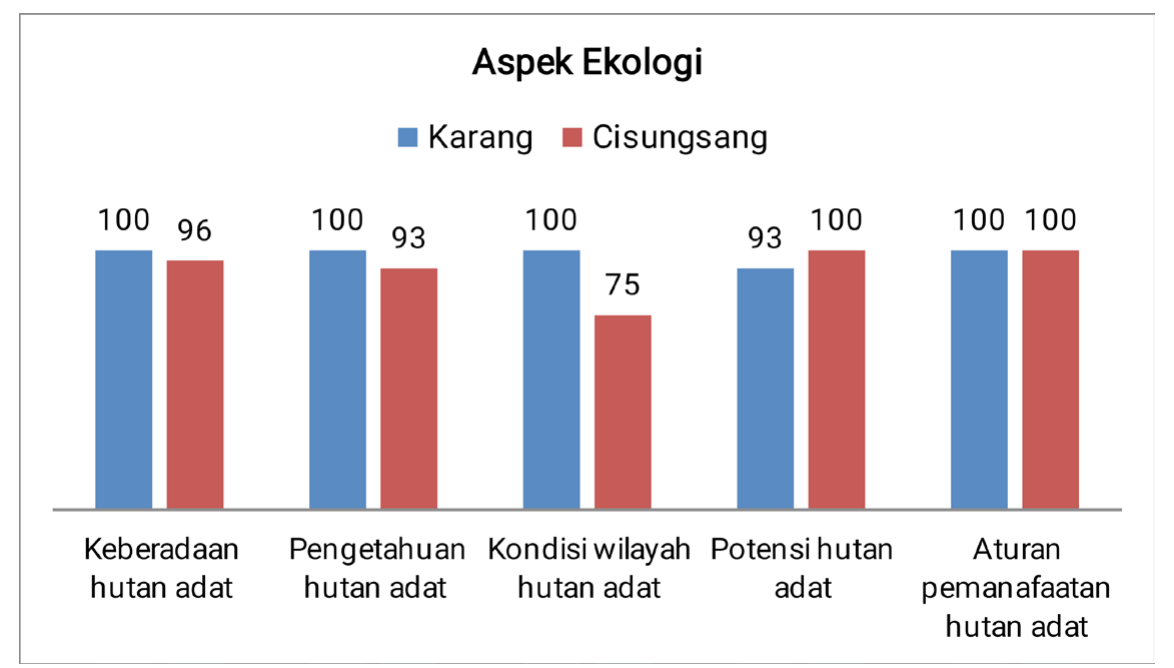

Sumber (Source): Data primer (Primary data)

Gambar 3 Persepsi masyarakat dari aspek ekologi

Figure 3 Community perceptions from the ecology aspects. 
adat adalah positif. Potensi yang ada di lahan garapan yaitu sawah, kebun buahbuah, pohon kayu-kayuan, sumber mata air, dan fauna. Masyarakat memahami zona yang dapat dimanfaatkan untuk lahan garapan adalah menggunakan pola usaha tumpangsari.

Persepsi tentang aturan secara tertulis dan syarat dalam pemanfaatan hutan adat juga positif, baik di Kasepuhan Karang maupun di Kasepuhan Cisungsang. Hutan garapan dapat digarap oleh anggota masyarakat hukum adat dengan pembagian sesuai arahan jaro (Kepala Desa/perangkat adat) atas nama abah untuk Kasepuhan Karang. Hutan titipan (leuweung titipan) tidak boleh ditebang dan harus dijaga, jika menebang harus menanam tiga bibit pohon sebagai gantinya. Ritual yang dilakukan dalam pengelolaan hutan di antaranya adalah syukuran untuk kesuburan dan keberkahan lahan garapan.

Di Kasepuhan Cisungsang, pada hutan titipan juga tidak boleh ditebang, sedangkan untuk hutan tutupan (leuweung tutupan) boleh melakukan tumpangsari tetapi tidak boleh merusak hutan. Penebangan pohon harus ada izin dari ketua adat, keperluannya harus jelas apakah untuk kepentingan pribadi atau bersama, dan tidak boleh dijual.

\section{KESIMPULAN DAN SARAN}

\section{A. Kesimpulan}

Persepsi masyarakat hukum adat Kasepuhan Karang dan Kasepuhan Cisungsang terhadap hutan ditinjau dari aspek sosial, ekonomi, dan ekologi umumnya positif, baik dalam menjaga, mengelola, dan memanfaatkan hutan adatnya. Dari hasil penelitian, kondisi hutan dan persepsi masyarakat terhadap hutan pada Kasepuhan Karang lebih baik dibandingkan dengan kondisi hutan pada Kasepuhan Cisungsang. Hal ini karena lembaga adat dan lembaga pemerintahan saling mendukung dan berkoordinasi.
Masyarakat hukum adat Kasepuhan Karang dan Kasepuhan Cisungsang memiliki hubungan yang jelas antara tanah yang menjadi sumber kehidupannya dengan alam sekitarnya. Hubungan tersebut diatur dalam sistem pengelolaan kelembagaan adat, hukum adat, norma adat, batas-batas, dan luasan yang jelas. Masyarakat hukum adat, baik Kasepuhan Karang maupun Kasepuhan Cisungsang bergantung pada hutan sebagai sumber kehidupan, obatobatan, dan bahan-bahan kerajinan tangan. Hutan juga menjadi tempat pelaksanaan ritual adat, sumber pangan, dan sumber mata air yang dipertahankan dan diwariskan dari generasi ke generasi.

Pengakuan terhadap keberadaan hutan adat sangat berpengaruh terhadap pengelolaan hutan adat dari masing-masing masyarakat hukum adat. Kasepuhan Karang telah ditetapkan hutan adatnya sehingga pengelolaan hutan adat menjadi jelas. Kasepuhan Cisungsang belum mendapatkan penetapan hutan adat, hal ini menjadi salah satu kendala karena lokasi hutan adat berada dalam kawasan hutan TNGHS.

\section{B. Saran}

Persepsi masyarakat hukum adat Kasepuhan Karang dan Kasepuhan Cisungsang dari aspek ekologi sangat tinggi. Masyarakat hukum adat cukup diuntungkan dari aspek ekonmi dan membuat mereka lebih peduli terhadap aspek ekologi/ lingkungan. Hal ini dapat dimanfaatkan oleh pemerintah pusat dan pemerintah daerah untuk melaksanakan program-program lingkungan dan pemberdayaan masyarakat sekitar hutan. Program eko-eduwisata menjadi salah satu hal yang menarik untuk diterapkan di kedua masyarakat hukum adat tersebut. Lembaga adat dan lembaga desa bekerja sama dengan pemerintah daerah untuk melaksanakan program-program tersebut sehingga dapat meningkatkan kesejahteraan masyarakat dan melestarikan hutan. 


\section{UCAPAN TERIMA KASIH (ACKNOWLEDGEMENT)}

Penulis mengucapkan terimakasih kepada masyarakat hukum adat Kasepuhan Karang dan Kasepuhan Cisungsang, Pemerintah Kabupaten Lebak, dan Pusat Penelitian dan Pengembangan Sosial, Ekonomi, Kebijakan, dan Perubahan Iklim yang telah membantu dalam kegiatan penelitian ini.

\section{DAFTAR PUSTAKA}

Al Ulya, A. N., Leksono, S. M., \& Khastini, R. O. (2017). Biodiversitas dan potensi jamur Basidomycota di kawasan Kasepuhan Cisungsang, Kabupaten Lebak, Banten. AlKauniyah: Journal of Biology, 10(1), 9-16. https://doi.org/10.15408/kauniyah.v10i1.4513.

Amalia, D. C. (2019). Pola penguasaan dan pemanfaatan lahan pasca-penetapan Hutan Adat Kasepuhan Karang (Tesis). Institut Pertanian Bogor, Bogor.

Ariawan, K. \& Surati. (2017). Pengetahuan dan harapan masyarakat terhadap perubahan peruntukan kawasan hutan di Kabupaten Indragiri Hilir. Jurnal Penelitian Sosial dan Ekonomi Kehutanan, 14(3), 205-217. https:// doi.org/10.20886/jpsek.2017.14.3.205-217.

Arizona, Y., Malik, \& Ishimora, I. L. (2017). Pengakuan hukum terhadap masyarakat adat: tren produk hukum daerah dan nasional pascaPutusan MK 35/PUU-X/2012 (Outlook Epistema 2017). Jakarta: Epistema Institute.

Azwar, S. (2010). Sikap manusia, teori dan pengukurannya. Yogyakarta: Pustaka Belajar.

BPS Kabupaten Lebak. (2020a). Kecamatan Cibeber dalam angka 2020. Lebak: Badan Pusat Statistik Kabupaten Lebak, Banten.

BPS Kabupaten Lebak. (2020b). Kecamatan Muncang dalam angka 2020. Lebak: Badan Pusat Statistik Kabupaten Lebak, Banten.

Desmiwati \& Surati. (2018). Upaya memperjuangkan peraturan daerah tentang pengakuan, perlindungan dan pemberdayaan masyarakat hukum adat kasepuhan Kabupaten Lebak, Banten. Jurnal Analisis Kebijakan Kehutanan, 15(2), 165-178.

Fajrianda, M., Bakar, Y. A., \& Syamsidik. (2017). Persepsi masyarakat terhadap konservasi hutan mangrove dan bencana di Desa Leuge, Kabupaten Aceh Timur. Jurnal Ilmu Kebencanaan, 4(1), $1-5$.
Hidayat, D. C., Surati, Sakuntaladewi, N., Sylviani, \& Ariawan, K. (2020). Value of vegetation diversity for indigenous (adat) community of Kasepuhan Karang. IOP Conference Series: Earth and Environmental Science.

Hidayat, H., Yogaswara, H., Herawati, T., Blazey, P., Wyatt, S., \& Howitt, R. (2018). Forests, law and customary rights in Indonesia: implications of a decision of the Indonesian Constitutional Court in 2012. Asia Pacific Viewpoint, 59(3), 293-308. https://doi.org/10.1111/apv.12207.

Kartodiharjo, H. (2016). Belajar dari berbagai pengalaman multi-pihak. Makalah disajikan dalam Workshop Strategi dan Gerakan Bersama Resolusi Konflik Agraria di Kawasan Hutan, Bogor: IPB.

Keputusan Bupati Lebak No. 430/Kep.298/ Disdikbud/2013 tentang Pengakuan Keberadaan Masyarakat Adat di Wilayah Kesatuan Adat Banten Kidul di Kabupaten Lebak.

Keputusan Menteri LHK No. 6744/MenLHKPSKL/KUM.1/12/2016 tentang Penetapan Pencantuman Hutan Adat Kasepuhan Karang Seluas \pm 486 Ha di Desa Jagaraksa Kecamatan Muncang Kabupaten Lebak Provinsi Banten.

Keputusan Menteri LHK No. 6748/MenLHK-PSKL/ KUM.1/12/2016 tentang Penetapan Hutan Adat Kasepuhan Karang Seluas \pm 462 Ha di Desa Jagaraksa Kecamatan Muncang Kabupaten Lebak Provinsi Banten.

Latupapua, Y. T. (2011). Persepsi masyarakat terhadap potensi objek daya tarik wisata pantai di Kecamatan Kei Kecil, Kabupaten Maluku Tenggara. Jurnal Agroforestri, 6(2), 92-102. https://doi.org/https://ojs3.unpatti.ac.id/index. php/jhppk/article/view/1319/1086.

Lestari, T., Agussabti, \& Alibsyah, M. R. (2014). Partisipasi masyarakat adat dalam konservasi sumberdaya hutan di Kecamatan Kota Jantho, Kabupaten Aceh Besar. Jurnal Manajemen Sumberdaya Lahan, 3(2), 506-517.

Manuaba, I. B. P., Satya Dewi, T. K., \& Kinasih, S. E. (2012). Mitos, masyarakat adat, dan pelestarian hutan. Atavisme, 15(2), 235. https:// doi.org/10.24257/atavisme.v15i2.63.235-246.

Nababan, A. (2014). Memperkuat posisi dan peran masyarakat adat dalam pengelolaan sumber daya alam dan lingkungan hidup di Indonesia. In I. Hakim \& L. R. Wibowo (Eds.), Hutan Untuk Rakyat Jalan Terjal Reforma Agraria di Sektor Kehutanan (pp. 145-156). Yogyakarta: LKiS.

Novayanti, D., Banuwa, I. S., Safe'i, R., Wulandari, C., \& Febryano, I. G. (2017). Analisis faktorfaktor yang mempengaruhi persepsi masyarakat dalam pembangunan hutan tanaman rakyat 
pada KPH Gedong Wani. Jurnal Hutan dan Masyarakat, 9(2), 61-74.

Novianti, R. (2016). Leuit Si Jimat: wujud solidaritas sosial masyarakat di Kasepuhan Sinarresmi. Jurnal Patanjala, 8(2).

Nuryanto \& Machpudin, I. (2008). Kajian pola kampung dan rumah tinggal warga Kasepuhan Kesatuan Adat Banten Kidul di Sukabumi Selatan-Jawa Barat. Bandung: Universitas Pendidikan Indonesia.

Pamungkas, H. S. R., Thayib, H., \& Inswiasri. (2015). Potential distribution pattern of artisanal gold mining's mercury waste in Cisungsang village, Lebak District, Banten. Jurnal Ekologi Kesehatan, 14(3), 195-205.

Peraturan Daerah Kabupaten Lebak Provinsi Banten Nomor 8 Tahun 2015 tentang Pengakuan, Perlindungan dan Pemberdayaan Masyarakat Hukum Adat Kasepuhan.

Prabowo, S. A., Basuni, S., \& Suharjito, D. (2010). Konflik tanpa henti: permukiman dalam kawasan Taman Nasional Halimun Salak. Jurnal Manajemen Hutan Tropika, 16(3), 137-142. https://doi.org/10.7226/jmht.16.3.

Pratiwi, R., Nitibaskara, T. U., \& Salampessy, M. L. (2019). Kelembagaan masyarakat dalam pengelolaan hutan adat (studi kasus di Kasepuhan Pasir Eurih, Desa Sindanglaya, Kecamatan Sobang, Kabupaten Lebak, Provinsi Banten). Jurnal Belantara, 2(1), 62-69. https:// doi.org/10.29303/jbl.v2i1.131.

Rahmawati, R., Darusman, D., \& Hermawan, D. (2017). Strategi adaptasi masyarakat lokal untuk tata kelola sumber daya hutan berkelanjutan. Bogor: Unida Pers.

Ramdhaniaty, N. (2018). Perempuan adat non elit, eksklusi berlapis, dan perjuangan hak kewarganegaraan atas hutan adat (Tesis). Sekolah Kajian Stratejik dan Global, Universitas Indonesia, Jakarta.

Restiyawan, A. A. (2016). Persepsi mahasiswa pendidikan ekonomi terhadap keberadaan bank mini di Program Studi Pendidikan Ekonomi Undiksha. Jurnal Program Studi Pendidikan Ekonomi, 7(1), 1-10.
Satriadi, Y. P. \& Somantri, R. A. (2016). Upacara Munar Lembur pada komunitas adat Kasepuhan Cisungsang, Kabupaten Lebak, Banten. Patanjala: Jurnal Penelitian Sejarah dan Budaya, 8(2), 155-170. https://doi.org/10.30959/ patanjala.v8i2.70.

Subarudi. (2014). Kebijakan pengelolaan hutan adat pasca-Putusan Mahkamah Konstitusi No. 35/PUU-X/2012: suatu tinjauan kritis. Jurnal Analisis Kebijakan Kehutanan, 11(3), 207-224.

Surati. (2014). Analisis sikap dan perilaku masyarakat terhadap Hutan Penelitian Parung Panjang. Jurnal Penelitian Sosial dan Ekonomi Kehutanan, 11(3), 339-347.

Surati, Sylviani, Sakuntaladewi, N., Irawanti, S., Ariawan, K., \& Hidayat, D. C. (2018). Rasionalitas persyaratan hutan adat dalam mendukung legalitas hutan (Laporan Hasil Penelitian). Bogor: Pusat Litbang Sosial Ekonomi Kebijakan dan Perubahan Iklim.

Sylviani, Surati, Sakuntaladewi, N., \& Sumirat, B. K. (2020). Adat community and climate change adaptation measures: case of Kasepuhan Karang. IOP Conference Series: Earth and Environmental Science, 487(1). https://doi.org/10.1088/17551315/487/1/012005.

Tansia, T. G. (2016). Sumber daya penghidupan masyarakat Kasepuhan Cisungsang, Kabupaten Lebak-Banten. Lembaran Masyarakat: Jurnal Pengembangan Masyarakat Islam, 2(2), 97-124.

Wahyuni, N. I. \& Mamonto, R. (2012). Persepsi masyarakat terhadap taman nasional dan sumber daya hutan: studi kasus Blok Aketawaje, Taman Nasional Aketawaje Lolobata. Info BPK Manado, 2(1), 1-16.

Zakaria, Y. R. (2016). Strategi pengakuan dan perlindungan hak-hak masyarakat (hukum) adat: sebuah pendekatan sosio-antropologis. BHUMI: Jurnal Agraria dan Pertanahan, 2(2), 133-150. 